\title{
Is There an Increased Complications Rate in After-Hours Colorectal Surgery?
}

Bogdan SOCEA', Oana HALAU², Ovidiu Gabriel BRATU³, Alexandru Constantin CARAP'1, Tiberiu Paul NEAGU ${ }^{4}$, Dumitru Cristinel BADIU ${ }^{5}$, Vlad Denis CONSTANTIN ${ }^{1}$

\begin{abstract}
When a surgical team is dealing with an after-hours colorectal surgery, they are actually confronting with a chain of elements and events, some linked to the patient and severity of the surgical case, others related to the medical team ability to cooperate, from nurses to surgeon and anesthetist.

There is a series of differences between elective and emergency performed surgeries, two of them and most important elements are the patient (disease type, age, preoperative condition) and the operating team (experience, technical performance after-hours, especially at night).
\end{abstract}

Keywords: complications rate, emergency colorectal surgery, after-hours surgery.

\section{Rezumat}

Atunci când o echipă chirurgicală realizează o intervenție chirurgicală colorectală în urgență, la ore târzii, se confruntă de fapt cu un lanț de elemente și evenimente, unele legate de pacient și severitatea cazului chirurgical, altele legate de capacitatea echipei medicale de a coopera, de la asistente medicale la chirurg și anestezist.

Există o serie de diferențe între intervențiile chirurgicale elective și cele de urgență, două dintre ele și cele mai importante elemente fiind pacientul (tipul bolii, vârsta, starea preoperatorie) și echipa operatorie (experiență, performanță tehnică după multe ore de muncă, mai ales noaptea).

Cuvinte cheie: rata de complicații, chirurgie colorectală de urgență, chirurgie la ore târzii.

\footnotetext{
${ }^{1}$ Department of Surgery, "Sf. Pantelimon" Emergency Clinical Hospital, „Carol Davila" University of Medicine and Pharmacy, Bucharest, Romania

${ }^{2}$ Department of Surgery, „Sf. Pantelimon" Emergency Clinical Hospital, Bucharest, Romania

${ }^{3}$ Department of Urology, Clinical Military Central Hospital, "Carol Davila" University of

${ }^{4}$ Department of Plastic Surgery and Reconstructive Microsurgery, Emergency Clinical Hospital, „Carol Davila" University of Medicine and Pharmacy, Bucharest, Romania

${ }^{5}$ Department of Surgery, "Bagdasar-Arseni" Emergency Clinical Hospital, „Carol Davila" University of Medicine and Pharmacy, Bucharest, Romania
}

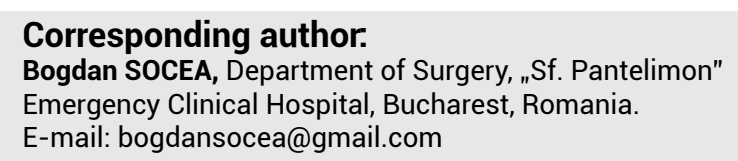

Corresponding author.

Bogdan SOCEA, Department of Surgery, „Sf. Pantelimon” Emergency Clinical Hospital, Bucharest, Romania.

E-mail: bogdansocea@gmail.com 


\section{INTRODUCTION}

To have an answer to this question, we have to understand that there is a vast group of potential factors that are of a paramount importance in every colorectal surgery: gender, age, the level of damage of the bowelperforation, ischemia, neoadjuvant radiotherapy, ASAscore, perioperative prepare of the patient with antibiotics and mechanical bowel preparation, associated illnesses. In addition to the aforementioned patient related factors, there are also surgical factors: laparoscopic vs. open surgery, anastomotic configuration- manual or mechanical, prolonged operating time, stress level of the surgical team performing after hours.

\section{DISCUSSION}

In elective colorectal surgery the main advantage is the patient-surgeon relationship. From the patient's point of view, he is more relaxed, he is prepared physical and psychical prepared, well investigated and in some cases adjuvant therapy is administrated. The surgical team knows the patient, his illness status, had had the time to analyze the case, acknowledge a treatment plan, agree on the type of surgical procedure.

To reduce surgical site infection, before elective surgery, the bowel is prepared mechanical and with antibiotics. Mechanical bowel preparation is considerate the standard in surgical practice by decreasing intralumenal fecal mass there for the bacterial loud, das for reducing the rate of post operator infections and complications. Preparing the bowel for colorectal surgery includes a variety of interventions: administration of oral laxative (polyethylene glycol, magnesium citrate, sodium phosphate), liquid diet on the day before surgery and preoperatory enema ${ }^{1}$. In addition to mechanical bowel preparation for the preoperative regimen, administration of per os or intravenous antibiotics has been found $f$ a great benefit in decreasing the rate of surgical site infection ${ }^{2}$.

Emergency colorectal surgery has a high rate of complications and mortality. The patient that comes at the emergency room is unaware of his illness, it is not investigated and has incomplete bowel preparation. Undiagnosed advanced colorectal cancer and various benign colon diseases complicated with perforation, obstruction or ischemia require emergency surgery, situation in which the act of surgery itself rises the rate of morbidity and mortality ${ }^{3}$. In these cases, the surgical team is dealing with a patient that can associate pne- umonia, sepsis, hemorrhage and renal failure, major symptoms threatening the life of the patient.

Undergoing colorectal surgery without the bowel prepared, the patient has a higher risk of anastomotic leakage, a major complication that occurs after surgery. In addition, ischemia, atherosclerosis, hypotension are leading risk factors for anastomotic fistula ${ }^{4}$. In this unfortunate case, the patient's mortality rises, the exposure to intestinal fluid damages the homeostasis of the organism, the cellular matrix das for higher rates of sepsis and post operator wound complications.

In after hour surgery, beside the gravity of the emergency case, the surgical team must struggle with the stress and exhaustion accumulated during the day. Diminish non-technical skills of the operating team at night, like management or teamwork skills and situational comprehension, contribute to higher complication rates. Situational awareness it is defined as the ability of the physician to observe, understand and predict events in the operating room, abilities diminished at night and significantly associated with technical errors ${ }^{5}$. Nevertheless, situation awareness doesn't affect only the operating team, teamwork and management skills may have an important impact on the anesthetists and nurses may, reflecting on the surgical patient and increasing potential lethal risks ${ }^{6}$.

Technical and non-technical skills performance and quality of the on-call staff are influenced by the leak of sleep, level of stress accumulated during the day. Communication errors are most common cause of unfortunate events, the atmosphere within the operating room has a direct influence on the quality of care, with direct proportional post-operator consequences ${ }^{7}$.

The working hours of surgeons have been a topic of debate in recent years. Sleep deprivation could negatively impact the cognitive function and performance, resulting in an increased risk of medical errors. This is an ethical problem for the patients, who have to achieve the best treatment possible. There are several studies that tried to find the best hours for surgeons to operate and whether sleep-deprivation affects their surgical skills ${ }^{8}$.

\section{CONCLUSIONS}

Colorectal surgery, elective or after-hour, exposes the patient to a majority of events and factors that affect his safety and increases the mortality and morbidity. Nevertheless, after-hours surgery is more complex, the surgeon confronts with an unprepared patient and in a 
short amount of time he must investigate, analyses and decide the therapeutic conduit.

After-hour surgery can mean a patient that has hemorrhage risk, unprepared colon, mechanical and with antibiotics, exposes the patient to bacteria and the risk of post operator infection, anastomosis leaking, peritonitis, sepsis, wound complications; a more stressful environment for both the patient and the operating team.

Teamwork, cooperation and understanding between surgeon, nurses and anesthetist is an important element in the chain that assures the patient's safety, element

\section{References}

1. Cagla Eskicioglu, Shawn S. Forbes, Darlene S. Fenech and Robin S. McLeod. Preoperative bowel preparation for patients undergoing elective colorectal surgery: a clinical practice guideline endorsed by the Canadian Society of Colon and Rectal Surgeons; Can J Surg 2010 Dec; 53(6): 385-395.

2. Vo $E$, Massarweh NN, Chai CY, et al. Association of the addition of oral antibiotics to mechanical bowel preparation for left coIon and rectal cancer resections with reduction of surgical site infections. JAMA Surg. 2018;153(2):114-121.

3. Kwan TL, Lai F, Lam CM, Yuen WC, Wai A, Siu YC, Shung E, Law WL. Population-based information on emergency colorectal surgery and evaluation on effect of operative volume on mortality. World J Surg. 2008 Sep; 32(9):2077-82.

4. Niels Komen, Jan-Willen Dijk, Zarina Lalmahomed, Karel Klop, Wim Hop, Gert-Jan Kleinrensink, Hans Jeekel, W. Ruud Schouten and Johan F. Lange. After-hours colorectal surgery: a risk that needs improvement in order to progress in the exhausting environment that the operating room offers.

\section{Compliance with ethics requirements:}

The authors declare no conflict of interest regarding this article.

The authors declare that all the procedures and experiments of this study respect the ethical standards in the Helsinki Declaration of 1975, as revised in 2008(5), as well as the national law. Informed consent was obtained from all the patients included in the study. factor for anastomotic leakage. Int J Colorectal Dis. $2009 \mathrm{Jul}$; 24(7): 789-795. doi: 10.1007/s00384-009-0692-4.

5. Mishra A et al (2008) The influence of non-technical performance on technical outcome in laparoscopic cholecystectomy. Surg Endosc 22(1):68-73.

6. Catchpole $\mathrm{K}$ et al (2008) Teamwork and error in the operating room: analysis of skills and roles. Ann Surg 247(4):699-706.

7. Sacks GD, Shannon EM, Dawes AJ, Rollo JC, Nguyen DK, Russell MM, et al. Teamwork, communication and safety climate: a systematic review of interventions to improve surgical culture. BMJ Qual Saf. 2015;24:458-467. doi: 10.1136/ bmjqs-2014-003764.

8. Socea B, Bobic S, Moculescu C, Nica AA, Diaconu CC, Constantin VD, Baleanu VD, Tenea Cojan TS. Surgical malpractice in relation to long calls. Proceedings of the XIIIth Conference on Bioethics (Iasi, Romania, 8-10 november 2018), Filodiritto Editori, 2019, ISBN 978-88-85813-58-8. 
